\title{
Prognostic factors of poor outcome in patients with upper limb replantation surgery admitted to the icu
}

\author{
E Portugal Rodríguez, E Martínez Barrio, E Nevado Sánchez, A Rodríguez Vega, A Berrazueta Sánchez de Vega, \\ D Armesto Formoso, A Zabalegui Pérez, M Martínez Barrios, JA Fernández Ratero, S Puerto Corrales
}

From ESICM LIVES 2015

Berlin, Germany. 3-7 October 2015

\section{Intr}

Our University Hospital is one of the national reference centers in upper extremity replantation surgery (ERS) (the transfer is carried out on air transportation by the National Transplant Organization, NTO). Therefore, it is important to optimize postoperative care in the ICU that may influence replantation evolution.

\section{Objectives}

To describe the characteristics of patients undergoing this surgery admitted to the ICU and to evaluate prognostic factors related with bad outcome [2].

\section{Methods}

Observational study of patients with ERS during a period of seven years (2008-2014). Computer research of electronic medical records in databases was conducted. We obtained a sample of 60 cases and classified them into two groups: good and poor outcome. We analyzed: epidemiological variables (age, smoking, diabetes, arteriopathy) variables related with injury mechanism (degloving, flattening, large bone lesion, neural lost and vascular affectation), surgery and postoperative care (amines, mechanical ventilation, transfusion, ICU stay).

We compared the factors associated with poor outcome in both groups

\section{Results}

In our sample of 60 cases $85 \%$ were male, mean age was 47,13 years, and no differences in previous comorbidities were observed. We found significant differences between the injury mechanism and the presence of large bone and

Burgos University Hospital, Burgos, Spain
Table 1

\begin{tabular}{|c|c|c|c|}
\hline Variable & $\begin{array}{l}\text { Good } \\
\text { outcome } \\
(n=30)\end{array}$ & $\begin{array}{l}\text { Bad outcome } \\
\text { (amputation, } \\
\mathrm{n}=30 \text { ) }\end{array}$ & $\begin{array}{l}P \\
\text { value }\end{array}$ \\
\hline $\begin{array}{l}\text { Injury mechanism(\%) } \\
\text { (degloving, flattening) }\end{array}$ & 34.8 & 65.2 & 0.09 \\
\hline Large bone lesion(\%) & 21.7 & 78.3 & 0.00 \\
\hline $\begin{array}{l}\text { Large vascular } \\
\text { affectation (\%) }\end{array}$ & 18.8 & 81.3 & 0.00 \\
\hline Large neural lost(\%) & 44.7 & 55.3 & 0.11 \\
\hline $\begin{array}{l}\text { Warm ischemia time } \\
\text { (mean hours } \pm \text { SD) }\end{array}$ & $4,0 \pm 1,44$ & $4.36 \pm 1.45$ & 0.57 \\
\hline $\begin{array}{l}\text { Surgery time (median } \\
\text { hours, IQR) }\end{array}$ & $\begin{array}{l}4.00(3,15- \\
7,50)\end{array}$ & $5.00(3.00-8.30)$ & 0.61 \\
\hline
\end{tabular}

vascular lesion (Table 1). Time of ischemia and surgery were comparable. There were no treatment differences in the ICU in both groups. ICU replantation survival was $93,3 \%$, with $10 \%$ of early reoperation due to arterial thrombosis.

\section{Conclusions}

In our sample, large bone and vascular affectation were the factors associated with poor replantation outcome, in patients with upper extremity amputation. No differences related with surgical or postoperative care variables were observed. Replantation survival rates, and need of reoperation in our series, were consistent with literature data [3].

Published: 1 October 2015

\section{References}

1. Nick Brinkman J, H. Derks Lieke, Klimek Markus, et al: Perioperative Fluid Management and Use of Vasoactive and Antithrombotic Agents in Free 
Flap Surgery: A Literature Review and Clinical Recommendations.

J Reconstr Microsurg 2013, 29:357-366.

2. Masoomi, et al: Predictive risk factors of free flap thrombosis in breast reconstruction surgery. Microsurgery 2014, March.

3. Prucz RB, Friedrich JB: Upper Extremity Replantation: Current Concepts. Plast Reconstr Surg 2014, 133:333.

doi:10.1186/2197-425X-3-S1-A235

Cite this article as: Portugal Rodríguez et al:: Prognostic factors of poor outcome in patients with upper limb replantation surgery admitted to the icu. Intensive Care Medicine Experimental 2015 3(Suppl 1):A235.

\section{Submit your manuscript to a SpringerOpen ${ }^{\mathcal{O}}$ journal and benefit from:}

- Convenient online submission

- Rigorous peer review

- Immediate publication on acceptance

- Open access: articles freely available online

- High visibility within the field

- Retaining the copyright to your article

Submit your next manuscript at $\gg$ springeropen.com 